DOI URL: https://doi.org/10.3126/jbssr.v5i1.30195

\title{
Impact of Heuristics on Investment Decisions: The Moderating Role of Locus of Control
}

\author{
Jeetendra Dangol ${ }^{1}$ \\ Associate Professor \\ Faculty of Management, Tribhuvan University \\ Rashmita Manandhar ${ }^{2}$ \\ Freelance Researcher
}

\begin{abstract}
Article History
Received 10 April 2020

Reviewed 11 May 2020

Revised 21 May 2020

Accepted 26 May 2020

\section{Keywords}

rationality, heuristics, availability bias, representative bias, anchoring and adjustment bias, overconfidence bias, investment decision, locus of control
\end{abstract}

Journal of Business and Social Sciences Research (ISSN: 25422812). Vol V, No. 1, June 2020

\begin{abstract}
This paper aims to assess the impact of heuristics on the investment decision by analysing the effect of four heuristic biases, i.e., representativeness, availability, anchoring and adjustment, and overconfidence bias on rationality of Nepalese investor's investment decisionmaking and also examines the moderating effect of the internal locus of control in between. The study used 391 respondents based on a convenient sampling procedure, and structured questionnaire survey. The study result indicates that there is a significant relationship between irrationality in investment decision-making and all four heuristic biases. In addition, the study also concludes that locus of control has significant moderating effect in the relationship between investment decisions and three heuristic biases, i.e., availability, representative and anchoring bias. However, the study documents no moderation effect in case of relationship with overconfidence bias.
\end{abstract}

\section{Introduction}

The Efficient market hypothesis (EMH) theory is based on the assumption of investor's rationality. Fama (1970) asserts that stock prices quickly and correctly

${ }^{1}$ Dr Dangol holds a PhD degree from the Faculty of Management, Tribhuvan University. He is former Deputy Director of the School of Management Tribhuvan University (SOMTU). He has published 32 research papers in peer-reviewed journals, 3 research-related books and co-authored 5 textbooks in Accountancy. His email is: jdangol@gmail.com

${ }^{2}$ Ms Manandhar is an MBA graduate of the School of Management Tribhuvan University (SOMTU). She can be contacted at rashmi.mdhr07@gmail.com 
adjust to the new information hence no investor can generate abnormal returns. However, Latif et al. (2011) states that the majority of markets in the world do not follow EMH as markets are characterised by certain anomalies and biases. The immense research efforts have been observed in the last decade to find new models predicting market behaviour (Latif et al., 2011). These studies basically focus on behavioural aspects of investors.

The conventional finance assumes that individual investors make their investment decisions rationally. But, in practice, many investors trade excessively, buy stock with recommendation of others, and ignore fundamental value, indicating irrational behaviour in the marketplace (Tversky \& Kahneman, 1974). According to Latif et al. (2011), the under and overreaction of the market are due to the psychological reasons of the investors. The investment decision-making process affected by cognitive errors, fundamental heuristics and psychological biases (Baker \& Nofsinger, 2010). Hence, behavioural aspects and unavoidable psychological biases among human beings prevent them from making rational decisions.

According to Shefrin (2007), biases are predispositions towards error. Shefrin (2009) further explained that investors are influenced by a number of biases, errors, and illusions while making decisions. Due to heuristics, i.e., mental shortcuts, those errors and biases can be observed (Slugoski, Shields, \& Dawson, 1993).

The main objective of this paper is to examine the impact of heuristics, i.e., availability bias, representative bias, anchoring bias and overconfidence bias on the investment-decision. The paper also attempts to examine the moderating effect of the locus of control on the relationships between investment decisionmaking and all four biases.

\section{Literature Review, Hypotheses and Conceptual Framework}

This section discusses, mainly, impact of representativeness, availability, anchoring and adjustment, and overconfidence bias in investment decision-making.

\subsection{Investment Decision Making}

Merton (1987) emphasised on knowledge of finance, which influences the optimal and rational decision-making. However, studies over the past two decades have highlighted the behavioural phenomena of the investors' psychology which relate to perceptions, memories, and thoughts without awareness. The behavioural phenomena described errors in investment decisions by investors (Hilton, 2001). Baker and Nofsinger (2002) further opined that investor's thoughts and feelings can change the decision-making process from rational to irrational.

Behavioural finance studies attempt to link human aspects with financial models (Barber \& Odean, 1999). In this regard, Ritter (2003) argued that markets are informationally inefficient, which is contrary to philosophy of EMH. It indicates, investors are difficult to be rational and their investment decisions are influenced by their behavioural preconception. 
Impact of Heuristics on Investment Decisions The Moderating ... : Dangol, Manandhar

\subsection{Representative Bias and Investment Decision-Making}

Investors' investment decisions are always influenced by their mental shortcut and mental stereotypes (Shefrin, 2007). That is known as a cognitive heuristic, i.e., representative bias. In this regard, De Bondt and Thaler (1995) explained that representativeness is the degree of similarity that an event has with its parent population. Further, due to representativeness investors give more value to recent experience and they ignore the long-term average rate, (Ritter, 2003). Further, Shefrin (2008) viewed that representativeness places too much trust in stereotypes and leads individual investors to make forecasts based on cognitive heuristic, which are not appropriate for the relevant situation. In short, representativeness prevents people from thinking wisely.

Past studies have made significant efforts to highlight the factors of investors' representativeness behaviour and try to prove irrationality causes. For example, Toma (2015) found the positive effect of representativeness bias on investment-decisions. The author opined that representativeness bias is the main cause to increase individual investors' returns. Similarly, Badshah, Irshad and Hakam (2016) also found a positive relationship between investment decisions and representativeness bias. In the same line, Ikram (2016) showed that representativeness bias positively affected individual investors' trading behaviour. Moreover, Chen, Kim, Nofsinger, and Rui (2007) concluded that representativeness bias is the main cause of Chinese investors making trading mistakes or poor trading decisions. Besides, Lakonishok, Shleifer, and Vishny (1994) found that representativeness is the reason for companies engaging in poor investments. Hence, as per the findings of past literature the proposed hypothesis is:

$\mathbf{H}_{\mathbf{1}}$ : Representative bias is significantly associated with the degree of irrationality in investment decisions.

\subsection{Availability Bias and Investment Decision-Making}

A decision maker has better confidence and relies on the knowledge and skill to make investment decisions. Investors believe readily available information rather than examining other alternatives and procedures. So, availability bias causes investment decisions to be irrational (Folkes, 1988). Thus, investors prefer to invest in local more familiar companies based on easily available information (Waweru et al., 2008). According to Tversky and Kahneman (1974), it occurs due to the fact that the outcome easily comes to the mind of investors.

Availability bias among investors affects their investment decisions. Khan (2015) and Ikram (2016) found that availability bias positively affected investors' investment decisions. Investors compare a given firm's performance to a peer's performance, and react on the basis of securities performance information (Brauer \& Wiersema, 2012). Investor competition forces investors 
to react quickly to available information (Bowers et al., 2014) and to make rational judgments instead; they rely on shortcuts such as the heuristic availability that will lead to irrational decisions. Based on these reviews, the proposed hypothesis is:

$\mathbf{H}_{\mathbf{2}}$ : Availability bias is significantly associated with the degree of irrationality in investment decisions.

\subsection{Anchoring and Adjustment Bias and Investment Decision-Making}

Anchoring and adjustment are a cognitive heuristic bias that informs us about the propensity of human beings to overly rely on the first piece of knowledge received (the "anchor") when making decisions (Waweru et al., 2008). In the decision-making, anchoring and modification happens as investors use an initial piece of information to make judgments or judgements. When an anchor is set, all other assessments or decisions revolve around that anchor; this results in a mistake or bias in understanding certain knowledge around the anchor (Shah \& Mahmood, 2018). According to Kahneman and Tversky (1974), anchoring is a technique used in situations where people make estimations using certain initial values which are skewed towards the initial ones because different starting points yield different estimates.

Review of related literatures on anchoring bias indicated that anchoring and adjustment bias has significant impact on rationality of investment decision. Waweru et al. (2008) suggested that financial decisions of institutional investors on the Nairobi Stock Exchange were influenced by the anchoring and adjustment bias. Similarly, the anchoring and adjustment bias has a markedly negative impact on investment decisions made by individual investors actively trading on Pakistan Stock Exchange (Shah et al., 2018). Hence, based on these studies the next proposed hypothesis is:

$\mathbf{H}_{3}$ : Anchoring and adjustment bias is significantly associated with the degree of irrationality in investment decisions.

\subsection{Overconfidence Bias and Investment Decision-making}

Overconfidence bias is failure to recognise the boundaries of one's knowledge. The overconfidence bias shows success to own talent and ability, overestimating own talent which is related to the self-attribution bias (Bakar \& Chui Yi, 2016). Three characteristics, according to Moore and Healy (2008), suggested individuals that suffer from overconfidence bias: overestimation, over-placement and over-precision. In overestimation, people rely solely on their own abilities; it is the assumptions of the decision-maker regarding their own results rather than their actual performance. Over-placement means that people view themselves as better than others. Over-precision refers to investors whose judgment is excessively certain and ignores the risk factors associated with investment decisions. Shefrin (2007) reported that investor overconfidence has two principal 
implications. The first is the investors are making bad bets. Second, they trade more often leading to disproportionate trade volume.

Like other biases, overconfidence bias also impacts investor's decision. According to Kafayat (2014) and Shah et al. (2018), the overconfidence bias has a detrimental effect on rational investor decision-making. Waweru et al. (2008) viewed the overconfidence bias as having an effect on institutional investors' financial decisions. Based on these literatures, the proposed hypothesis is:

$\mathbf{H}_{4}$ : Overconfidence bias is significantly associated with the degree of irrationality in investment decisions.

\subsection{Moderating Role of Internal Locus of Control}

If a person feels that the desired result is due to his / her own, this is called internal control locus. By comparison, if a person believes that the successful result is due to external factors such as opportunity, chance, fate and powerful others, this is called the external control locus (Selart, 2005). Absence of willingness to accept their mistakes can lead the investor from biased decision-making (Davis \& Bobko, 1986). As a result, biased investors make irrational investment decisions.

According to Heckman, Stixrud and Urzua (2006), there is immense importance of different aspects of personality for various economic outcomes and one among the personality factors is locus of control. Some investors do not know their capabilities and risk too much, while some investors overestimate their capabilities and believe they can control or change market conditions (Gervais \& O dean, 2001). These investors assume that they are better than average (Kaustia \& Perttula, 2012), resulting in increased irrationality in their investment decisions.

The conceptual framework presents in figure 1.

Independent Variables Moderating Variable Dependent Variable

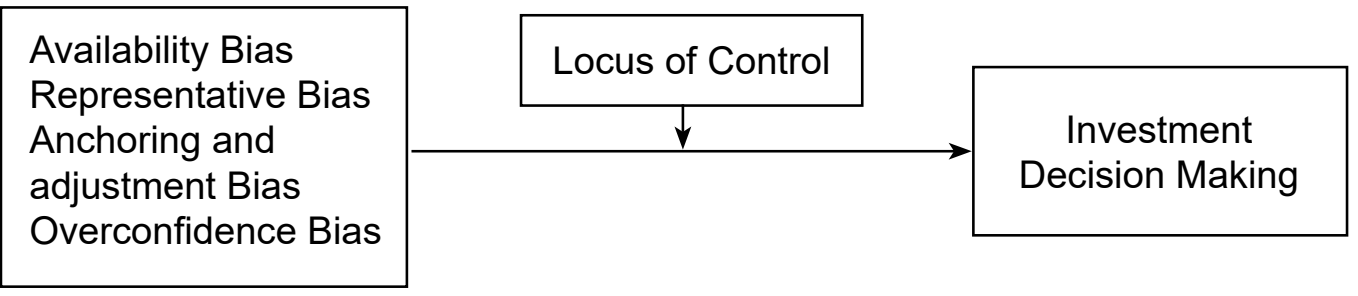

Figure 1.Conceptual framework

Based on these discussions, it can be concluded that the greater an investor's internal locus of influence, the more he would depend on heuristics-based decisions. Hence, the prior expectation of this paper is 
that the presence of an internal locus of control leads investors towards more biased and irrational investment decisions. Therefore, the proposed hypotheses are as under:

$\mathbf{H}_{5}$ : Internal locus of control moderates the relationship between representative bias and investment decision-making.

$\mathbf{H}_{6}$ : Internal locus of control moderates the relationship between availability bias and investment decision-making.

$\mathbf{H}_{\mathbf{7}}$ : Internal locus of control moderates the relationship between anchoring and adjustment biais and investment decision-making.

$\mathbf{H}_{\mathbf{8}}$ : Internal locus of control moderates the relationship between overconfidence and investment decision-making.

There is an expected positive relationship between the investment decisionmaking and all four independent variables: availability, representative, anchoring and adjustment, and overconfidence biases.

\section{Research Methods}

This paper employs causal-comparative research design. The population for the paper is all the individual investors who have traded in Nepal Stock Exchange (NEPSE). The exact population of the study, i.e., individual investors, are unknown. According to Godden (2004) for the unknown population, the sample size was determined, i.e. 384. However, data were collected from 391 investors from 16 brokerage firms located in Naxal, Kamalpokhari, Putalisadak and New Road area of Kathmandu Valley using a convenient sampling technique from June to July of 2019. The questionnaires were prepared in both English and Nepali languages, and distributed physically and collected later after getting them filled the response rate was 100 per cent.

Table 1

Reliability Analysis

\begin{tabular}{lll}
\hline Variables/ltems & No. of Statements & Cronbach's Alpha \\
\hline Availability Bias & 3 & 0.701 \\
Representative Bias & 5 & 0.703 \\
Anchoring and adjustment bias & 4 & 0.720 \\
Overconfidence Bias & 5 & 0.742 \\
Locus of control & 6 & 0.774 \\
Decision making & 5 & 0.702 \\
\hline
\end{tabular}

Note. Calculations based on the survey, 2019

The paper is based on primary data using structured questionnaires, which is adapted from Rasheed et al. (2018) and Waweru et al. (2008). The first section of the questionnaire is related to the demographic profile of the respondents 
such as gender, age, marital status, qualification, occupation, and investment experience. The second part consists of measures to identify availability, representative, anchoring and overconfidence heuristics along with the locus of control and decision-making method. In this part, a 5-point Likert scale has been used.

The reliability of the data is measured using Chronbach's Alpha. The value of Cronbach's Alpha for each variable is more than 0.7 , indicating data is reliable and fit for further statistical tests. The overall score of Cronbach's Alpha was found to be 0.887 when all the items were taken into account. The reliability of each variable is shown in Table 1.

The models for the data analysis are as follows:

IDM $=a+b_{1} A B+b_{2} R B+b_{3} A A B+b_{4} O B+e$

IDM $=a+b_{1} A B+b_{2} L C+b_{3}\left(A B^{*} L C\right)+e$

$I D M=a+b_{1} R B+b_{2} L C+b_{3}\left(R B^{*} L C\right)+e$

$I D M=a+b_{1} A A B+b_{2} L C+b_{3}\left(A A B^{*} L C\right)+e$

IDM $=a+b_{1} O B+b_{2} L C+b_{3}\left(O B^{*} L C\right)+e$

Where, IDM = Investment Decision Making, $A B=$ Availability bias, $R B=$ Representative bias, $A A B=$ Anchoring and adjustment bias, $O B=$ Overconfidence bias, $L C=$ Locus of control, $\mathrm{e}=$ Error of estimates

\section{Results and Discussions}

This section presents and discusses the results from the data analysis.

\subsection{Demographic Profile of Respondents}

The three-fourth respondents are male. Around two-third respondents are married. Majority of the respondents (two-third) have investment experience less than five years. The three-fourth of the respondents have very good academic qualification of bachelors' degree and above. Around three-fifth respondents are self-employed and salaried individuals.

\subsection{Correlation Analysis among Variables}

Table 2 shows correlation coefficient between all four biases bias and investment decision-making indicates that there is positive but weak relationship between availability bias and investment decision-making while is positive moderate relationship between rest of the three biases (representative, anchoring and overconfidence) and investment decision-making. Correlation coefficient between locus of control and investment decision-making is positive moderate relationship. In addition, the matrix also shows all the biases have positive correlation with each other. 
Table 2

Correlation among Variables

\begin{tabular}{lllllll}
\hline Variables & 1 & 2 & 3 & 4 & 5 & 6 \\
\hline 1. Availability Bias & 1 & & & & & \\
2. Representative Bias & $.401^{* *}$ & 1 & & & & \\
& $(0.000)$ & & & & & \\
3. Anchoring and Adjustment Bias & $.233^{* *}$ & $.571^{* *}$ & 1 & & & \\
& $(0.000)$ & $(0.000)$ & & & & \\
4. Overconfidence Bias & $.184^{* *}$ & $.366^{* *}$ & $.455^{* *}$ & 1 & & \\
& $(0.000)$ & $(0.000)$ & $(0.000)$ & & & \\
5. Locus of Control & $.195^{* *}$ & $.521^{* *}$ & $.526^{* *}$ & $.541^{* *}$ & 1 & \\
& $(0.000)$ & $(0.000)$ & $(0.000)$ & $(0.000)$ & & \\
6. Investment Decision Making & $.278^{* *}$ & $.321^{* *}$ & $.375^{* *}$ & $.369^{* *}$ & $.499^{* *}$ & 1 \\
& $(0.000)$ & $(0.000)$ & $(0.000)$ & $(0.000)$ & $(0.000)$ & \\
\hline
\end{tabular}

Note. Figures in parentheses are p-values. ${ }^{* *}$ Correlation is significant at the 0.01 level (2-tailed). The calculations based on the survey, 2019

There is a significant relationship between availability, representative, anchoring, overconfidence bias and irrationality in investment decision-making. It indicates that all the four heuristics biases affect Nepalese investors to their rationality in making investment decisions.

\subsection{Analysis of Impact of Heuristics on Investment Decision Making}

Table 3 consists of 15 models in total. Each model shows the result of regression analysis of different combinations of independent variables and a dependent variable. All these models are significant at 1 percent of significance level. All the models conclude that all the biases have a significant impact on investment decisions. But, the level of impact is even highest in case of overconfidence bias followed by anchoring bias. Representative bias is to have least impact on investment decisions.

The results are similar to Waweru et al. (2008), which concluded that representativeness, overconfidence; anchoring and availability bias affected the decisions of the institutional investors. In addition, it is also consistent with the finding of Rasheed et al. (2018) and Ikram (2016), who found that the representative bias and availability bias both have a significant positive impact on investor investment decisions. Khan (2015) found that availability, anchoring and representative bias have significant impact on the investment decisions of individual investors. Similarly, Chen et al. (2007); Lakonishok et al. (1994); Toma (2015); Badshah et al. (2016) are some of the studies that give the findings consistent with the finding of this paper. But on the contrary, Abdin et al. (2017) stated that availability and overconfidence biases do not directly impact on investment performance. 
Table 3

Regression Analysis

\begin{tabular}{|c|c|c|c|c|c|c|c|c|}
\hline \multirow[b]{2}{*}{ Model } & \multirow[b]{2}{*}{ Intercept } & \multicolumn{4}{|c|}{ Regression Coefficients (Beta) } & \multirow[b]{2}{*}{$\mathrm{R} 2$} & \multirow[b]{2}{*}{ SEE } & \multirow[b]{2}{*}{ F-Value } \\
\hline & & $\overline{\mathrm{AB}}$ & $\mathrm{RB}$ & $A A B$ & OB & & & \\
\hline 1 & $\begin{array}{l}2.657 \\
(0.000)\end{array}$ & $\begin{array}{l}0.265 \\
(0.000)\end{array}$ & & & & 0.074 & 0.627 & $\begin{array}{l}31.218 \\
(0.000)\end{array}$ \\
\hline 2 & $\begin{array}{l}2.261 \\
(0.000)\end{array}$ & & $\begin{array}{l}0.325 \\
(0.000)\end{array}$ & & & 0.103 & 0.617 & $\begin{array}{l}44.638 \\
(0.000)\end{array}$ \\
\hline 3 & $\begin{array}{l}2.159 \\
(0.000)\end{array}$ & & & $\begin{array}{l}0.359 \\
(0.000)\end{array}$ & & 0.141 & 0.604 & $\begin{array}{l}63.593 \\
(0.000)\end{array}$ \\
\hline 4 & $\begin{array}{l}2.331 \\
(0.000)\end{array}$ & & & & $\begin{array}{l}0.357 \\
(0.000)\end{array}$ & 0.143 & 0.603 & $\begin{array}{l}64.689 \\
(0.000)\end{array}$ \\
\hline 5 & $\begin{array}{l}2.013 \\
(0.000)\end{array}$ & $\begin{array}{l}0.166 \\
(0.001)\end{array}$ & $\begin{array}{l}0.255 \\
(0.000)\end{array}$ & & & 0.127 & 0.609 & $\begin{array}{l}28.306 \\
(0.000)\end{array}$ \\
\hline 6 & $\begin{array}{l}1.879 \\
(0.000)\end{array}$ & & $\begin{array}{l}0.160 \\
(0.006)\end{array}$ & $\begin{array}{l}0.272 \\
(0.000)\end{array}$ & & 0.157 & 0.599 & $\begin{array}{l}36.243 \\
(0.000)\end{array}$ \\
\hline 7 & $\begin{array}{l}1.744 \\
(0.000)\end{array}$ & & & $\begin{array}{l}0.252 \\
(0.000)\end{array}$ & $\begin{array}{l}0.253 \\
(0.000)\end{array}$ & 0.200 & 0.584 & $\begin{array}{l}48.357 \\
(0.000)\end{array}$ \\
\hline 8 & $\begin{array}{l}1.832 \\
(0.000)\end{array}$ & $\begin{array}{l}0.202 \\
(0.000)\end{array}$ & & & $\begin{array}{l}0.319 \\
(0.000)\end{array}$ & 0.184 & 0.589 & $\begin{array}{l}43.808 \\
(0.000)\end{array}$ \\
\hline 9 & $\begin{array}{l}1.718 \\
(0.000)\end{array}$ & $\begin{array}{l}0.194 \\
(0.000)\end{array}$ & & $\begin{array}{l}0.317 \\
(0.000)\end{array}$ & & 0.179 & 0.591 & $\begin{array}{l}42.155 \\
(0.000)\end{array}$ \\
\hline 10 & $\begin{array}{l}1.757 \\
(0.000)\end{array}$ & & $\begin{array}{l}0.216 \\
(0.000)\end{array}$ & & $\begin{array}{l}0.285 \\
(0.000)\end{array}$ & 0.182 & 0.589 & $\begin{array}{l}43.261 \\
(0.000)\end{array}$ \\
\hline 11 & $\begin{array}{l}1.621 \\
(0.000)\end{array}$ & $\begin{array}{l}0.170 \\
(0.001)\end{array}$ & $\begin{array}{l}0.087 \\
(0.150)\end{array}$ & $\begin{array}{l}0.275 \\
(0.000)\end{array}$ & & 0.183 & 0.590 & $\begin{array}{l}28.875 \\
(0.000)\end{array}$ \\
\hline 12 & $\begin{array}{l}1.567 \\
(0.000)\end{array}$ & & $\begin{array}{l}0.116 \\
(0.040)\end{array}$ & $\begin{array}{l}0.196 \\
(0.000)\end{array}$ & $\begin{array}{l}0.237 \\
(0.000)\end{array}$ & 0.208 & 0.581 & $\begin{array}{l}33.916 \\
(0.000)\end{array}$ \\
\hline 13 & $\begin{array}{l}1.392 \\
(0.000)\end{array}$ & $\begin{array}{l}0.169 \\
(0.000)\end{array}$ & & $\begin{array}{l}0.224 \\
(0.000)\end{array}$ & $\begin{array}{l}0.233 \\
(0.000)\end{array}$ & 0.228 & 0.574 & $\begin{array}{l}38.099 \\
(0.000)\end{array}$ \\
\hline 14 & $\begin{array}{l}1.547 \\
(0.000)\end{array}$ & $\begin{array}{l}0.150 \\
(0.002)\end{array}$ & $\begin{array}{l}0.156 \\
(0.003)\end{array}$ & & $\begin{array}{l}0.277 \\
(0.000)\end{array}$ & 0.202 & 0.584 & $\begin{array}{l}32.684 \\
(0.000)\end{array}$ \\
\hline 15 & $\begin{array}{l}1.343 \\
(0.000)\end{array}$ & $\begin{array}{l}0.155 \\
(0.001)\end{array}$ & $\begin{array}{l}0.051 \\
(0.390)\end{array}$ & $\begin{array}{l}0.201 \\
(0.000)\end{array}$ & $\begin{array}{l}0.228 \\
(0.000)\end{array}$ & 0.229 & 0.574 & $\begin{array}{l}28.740 \\
(0.000)\end{array}$ \\
\hline
\end{tabular}

Note. Figures in parentheses are $p$-values. where, $A B=$ Availability bias, $R B=$ Representative bias, $A A B=$ Anchoring and adjustment bias, $O B=$ Overconfidence bias, $S E E=$ Standard Error of Estimates. The calculations based on the Survey, 2019 


\subsection{Analysis of Moderation Effect of Locus of Control}

A moderator variable is a third variable that affects the strength of the relationship between a dependent and independent variable. The examination of moderation effect of locus of control in the relationship of investment decision-making with four different heuristics is explained in tables 4 to 7 . Each table consists of two models. Model 1 shows the linear relationship without moderation while model 2 deals with the relationship with moderation effect of locus of control.

Table 4

Regression Analysis to Test Moderation in Case of Availability Bias

\begin{tabular}{|c|c|c|c|c|c|c|c|c|}
\hline \multirow{2}{*}{ Independent Variables } & \multicolumn{4}{|c|}{ Model 1} & \multicolumn{4}{|c|}{ Model 2} \\
\hline & Beta & SE & $T$ & $p$-value & Beta & SE & $t$ & p-value \\
\hline Intercept & 1.285 & 0.185 & 6.962 & 0.000 & 1.373 & 0.186 & 7.365 & 0.000 \\
\hline Availability Bias (1) & 0.177 & 0.043 & 4.162 & 0.000 & 0.188 & 0.043 & 4.430 & 0.000 \\
\hline Locus of Control (2) & 0.453 & 0.043 & 10.560 & 0.000 & 0.423 & 0.044 & 9.564 & 0.000 \\
\hline Interaction $(1 * 2)$ & & & & & -0.063 & 0.024 & -2.570 & 0.011 \\
\hline Adjusted R2 & 0.279 & & & & 0.288 & & & \\
\hline F-value & 76.538 & & & & 0.549 & & & \\
\hline$p$-value & 0.000 & & & & 0.000 & & & \\
\hline
\end{tabular}

Note. Calculations based on the survey, 2019

Both models in table 4 are significant at 1 percent level of significance. Beta of interaction is -0.063 with $p$-value of $0.011(0.011<0.05)$, it indicates that interaction has a significant impact on the model. In addition, change in $\mathrm{R}^{2}$ by 0.011 also indicates that there exists significant moderation impact of locus of control in the relationship between availability bias and investment decision-making.

Table 5

Regression Analysis to Test Moderation in Case of Representative Bias

\begin{tabular}{|c|c|c|c|c|c|c|c|c|}
\hline \multirow{2}{*}{ Independent Variables } & \multicolumn{4}{|c|}{ Model 1} & \multicolumn{4}{|c|}{ Model 2} \\
\hline & Beta & SE & $\mathrm{T}$ & $p$-value & Beta & SE & $\mathrm{T}$ & $p$-value \\
\hline Intercept & 1.543 & 0.186 & 8.296 & 0.000 & 1.824 & 0.205 & 8.879 & 0.000 \\
\hline Representative Bias (1) & 0.085 & 0.052 & 1.624 & 0.105 & 0.056 & 0.052 & 1.063 & 0.289 \\
\hline Locus of Control (2) & 0.445 & 0.050 & 8.861 & 0.000 & 0.406 & 0.051 & 7.915 & 0.000 \\
\hline Interaction $(1 * 2)$ & & & & & -0.060 & 0.020 & -3.076 & 0.002 \\
\hline Adjusted R2 & 0.250 & & & & 0.266 & & & \\
\hline F-value & 66.028 & & & & 48.131 & & & \\
\hline p-value & 0.000 & & & & 0.000 & & & \\
\hline
\end{tabular}

Note. Calculations based on the survey, 2019

Both models in table 5 are significant with p-value of $0.00(p<0.05)$. Beta of interaction is -0.060 with $p$-value of $0.002(0.002<0.05)$, it shows that interaction has a significant impact in the model. In addition, change in $R^{2}$ by 0.016 also 
indicates that there exists significant moderation impact of locus of control in the relationship between representative bias and investment decision-making.

Table 6

Regression Analysis to Test Moderation in Case of Anchoring and Adjustment Bias

\begin{tabular}{|c|c|c|c|c|c|c|c|}
\hline \multirow{2}{*}{ Independent Variables } & \multicolumn{3}{|c|}{ Model 1} & \multicolumn{4}{|c|}{ Model 2} \\
\hline & Beta SE & $t$ & $p$-value & Beta & SE & $t$ & $\mathrm{p}$-value \\
\hline Intercept & $1.450 \quad 0.177$ & 8.178 & 0.000 & 1.672 & 0.196 & 8.52 & 0.000 \\
\hline Anchoring and adjustment Bias (1) & 0.1490 .049 & 3.036 & 0.003 & 0.126 & 0.049 & 2.542 & 0.011 \\
\hline Locus of Control (2) & 0.4080 .050 & 8.156 & 0.000 & 0.378 & 0.051 & 7.397 & 0.000 \\
\hline Interaction $(1 * 2)$ & & & & -0.055 & 0.021 & -2.56 & 30.011 \\
\hline Adjusted R2 & 0.263 & & & 0.273 & & & \\
\hline F-value & 70.410 & & & 49.80 & & & \\
\hline$p$-value & 0.000 & & & 0.000 & & & \\
\hline
\end{tabular}

Note. Calculations based on the Survey, 2019

Table 6 depicts both models are significant with $p$-value of $0.00(p<0.05)$. Beta of interaction is -0.055 with p-value of $0.011(0.011<0.05)$, it gives evidence that interaction has significant impact in the model to predict the value of the dependent variable. In addition, $R^{2}$ has changed by 0.010 this also indicates that there exists significant moderation impact of locus of control in the relationship between anchoring and adjustment bias and investment decision making.

Table7

Regression Analysis to Test Moderation in Case of Overconfidence Bias

\begin{tabular}{|c|c|c|c|c|c|c|c|}
\hline \multirow{2}{*}{ Independent Variables } & \multicolumn{3}{|c|}{ Model 1} & \multicolumn{4}{|c|}{ Model 2} \\
\hline & Beta SE & $T$ & $p$ & Beta & SE & $T$ & $p$ \\
\hline Intercept & 1.4670 .169 & 8.696 & 0.000 & 1.534 & 0.175 & 8.788 & 0.000 \\
\hline Overconfidence Bias (1) & 0.1700 .047 & 3.647 & 0.000 & 0.170 & 0.046 & 3.658 & 0.000 \\
\hline Locus of Control (2) & $0.404 \quad 0.048$ & 8.371 & 0.000 & 0.389 & 0.049 & 7.923 & 0.000 \\
\hline Interaction $(1 * 2)$ & & & & -0.035 & 0.024 & -1.468 & 30.143 \\
\hline Adjusted R2 & 0.270 & & & 0.272 & & & \\
\hline F-value for the model & 73.125 & & & 49.613 & & & \\
\hline$p$-value for the model & 0.000 & & & 0.000 & & & \\
\hline
\end{tabular}

Table 7 shows significance at 1 per cent level of significance for the both models. Interaction coefficient is found significant at 1 per cent of significance level; this indicates that there exists insignificant moderation impact of locus of control in the relationship between overconfidence bias and investment decision-making.

Ikram (2016) concluded that locus of control plays a moderating role between representative bias and investment decision but not in between availability bias and investment decision. A different conclusion is given by Rasheed et al. (2018), which states that internal locus of control neither moderates the relationship 
between representative bias and investment decision-making nor the relationship between availability bias and investment decision.

\subsection{Summary of Hypotheses}

There are altogether 8 hypotheses tested and results as shown in table 8 , out of which all, except one, are supported at 5 per cent level of significance.

Table 8

Summary of Hypotheses

Hypotheses

Results

$\mathrm{H} 1 \quad$ Representative bias is significantly associated with the degree of

Supported irrationality in investment decisions.

H2 Availability bias is significantly associated with the degree of irrationality Supported in investment decisions.

H3 Anchoring and adjustment bias is significantly associated with the degree of irrationality in investment decisions.

$\mathrm{H} 4$ Overconfidence bias is significantly associated with the degree of irrationality in investment decisions.

H5 Internal locus of control moderates the relationship between representative bias and investment decision making.

H6 Internal locus of control moderates the relationship between availability bias and investment decision making.

$\mathrm{H} 7 \quad$ Internal locus of control moderates the relationship between anchoring and adjustment bias and investment decision making.

H8 Internal locus of control moderates the relationship between overconfidence bias and investment decision making.

Supported

Supported

Supported

Supported

Supported

Not Supported

\section{Conclusion and Implications}

The Nepalese investors are influenced by heuristics biases. Despite this, most of the Nepalese investors are educated; they use mental shortcuts rather than rational judgments to select stocks. They rely on the most current and easily available information obtained from the market. Similarly, they make their investment decision based on the information from friends and family without any attempt to verify the information. In addition, there is a high tendency among Nepalese investors' investment decisions based on the performance of the representative stocks. In addition, Nepalese investors feel that they have access to all the required information and hence are capable of making good investment decisions. They believe that they can make the correct investment decision than others and all their successful investment is the result of their own skill and competency. All these feelings and confidence in oneself leads the investors to make quick decisions without making rational analysis. However, these feelings and behaviour of Nepalese investors are also influenced by the degree of locus of control the investors have. It is believed that people with high internal locus of 
control attribute the result of their decision to their own ability and responsibility; hence, they make more cautious and careful decisions.

The findings of this paper have various implications for investors, brokers and policy makers in Nepalese share market. Firstly, this paper will help investors to better understand their own behaviour by keeping in view the factors causing their decisions to deviate from wealth creation. This paper can make them aware of the impact of their own cognitive and emotional factors on their decisionmaking process which would be useful to improve the quality of decision-making in investment analysis. Secondly, investment brokerage houses may also provide more effective service and guidance to their clients once they are aware of heuristic biases hampering their investment decisions. Moreover, this paper helps stock market policy makers and regulators understand the mechanism and role of behavioural factors in the decision-making of investors. This would enable them to formulate policy and regulation considering these impacts.

In addition to these all, the paper will also fill the gap of inadequate research in the field of behavioural finance contextualising Nepalese stock market. This will also add value to current literature of heuristic biases in Nepalese stock market and provide avenues to the researchers to study this area in more detail in future.

\section{References}

Badshah, W., Irshad, S., \& Hakam, U. (2016). Effect of representativeness bias on investment decision making. Management and Administrative Sciences Review, $5(1), 26-30$.

Bakar, S., \& Chui Yi, A. N. (2016). The impact of psychological factors on investors' decision making in Malaysian Stock Market: A case of Klang Valley and Pahang. Procedia Economics and Finance, 35, 319 - 328.

Baker, H. K., \& Nofsinger, J. (2010). Behavioral finance: An overview. Behavioral Finance: Investors, Corporations, and Markets, 1-21.

Barber, B., Odean, T., \& Zhu, N. (2009). Systematic noise. Journal of Financial Markets, 12(4), 547-569.

Bowers, A. H., Greve, H. R., Mitsuhashi, H., \& Baum, J. A. (2014). Competitive parity, status disparity, and mutual forbearance: Securities analysts' competition for investor attention. Academy of Management Journal, 57(1), 38-62.

Chen, G., Kim, K., Nofsinger, J., \& Rui, O. (2007). Trading performance, disposition effect, overconfidence, representativeness bias and experience of emerging market investor. Journal of Behavioral Decision Making, 20(4), 425-451.

De Bondt, W. F., \& Thaler, R. H. (1995). Financial decision making in markets and firms: A behavioral perspective. Handbooks in Operations Research and Management Science, 9(13), 385-410.

Fama, E. F. (1970). Efficient capital markets: A review of theory and empirical Work. The Journal of Finance, 25(2), 383-417. 
Heckman, J. J., Stixrud, J., \&Urzua, S. (2006). The effects of cognitive and noncognitive abilities on labor market outcomes and social behavior. Journal of Labor Economics, 24, 411-482.

Ikram, Z. (2016). An empirical investigation on behavioral determinants on, impact on investment decision making, moderating role of locus of control. Journal of Poverty, Investment and Development, 26, 44-50

Kafayat, A. (2014). Interrelationship of biases: effect investment decisions ultimately. Theoretical and Applied Economics, 21(6), 85-110.

Khan, M. (2015). Impact of availability bias and loss aversion bias on investment decision making: Moderating role of risk perception. Journal of Research in Business Management, 1(2), 1-12

Lakonishok, J., Shleifer, A., \& Vishny, R. (1994). Contrarian investment, extrapolation and risk. Journal of Finance, 49(5), 1541-1578.

Latif, M., Arshad, S., Fatima, M., \& Farooq, S. (2011). Market efficiency, market anomalies, causes, evidences, and some behavioral aspects of market anomalies. Research Journal of Finance and Accounting, 2(9), 1-13.

Rasheed, M. H., Rafique, A., Zahid, T., \& Akhta, M. W. (2018). Factors influencing investor's decision making in Pakistan: Moderating the role of locus of. Review of Behavioral Finance, 10(1), 70-87.

Selart, M. (2005). Understanding the role of locus of control in consultative decision making: A case study. Management Decision, 43(3), 397- 412.

Shah, S. Z., Ahmad, M., \& Mahmood, F. (2018). Heuristic biases in investment decisionmaking and perceived market efficiency: A survey at the Pakistan stock exchange. Qualitative Research in Financial Markets, 10(1), 85-110.

Shefrin, H. (2008). A behavioral approach to asset pricing. London: Elsevier.

Shefrin, H. (2007). Behavioral corporate finance: Decisions that create value. Boston: McGraw-Hill/Irwin.

Shefrin, H. (2009). How psychological pitfalls generated the global financial crisis. In Insights into the global financial crisis. The CFA Institute Research Foundation.

Slugoski, B. R., Shields, H. A., \& Dawson, K. A. (1993). Relation of conditional reasoning to heuristic processing. Personality and Social Psychology Bulletin, 19(12), 158-166.

Toma, F. (2015). Behavioral biases of the investment decisions of Romanian Investors on the Bucharest Stock Exchange. Procedia Economics and Finance, 32, 200-207.

Tversky, A., \& Kahneman, D. (1974). Judgement under uncertainty: Heuristics and biases. Journal of Behavioral Science, 185, 1124-1131.

Waweru, N. M., Munyoki, E., \& Uliana, E. (2008). The effects of behavioural factors in investment decision-making: a survey of institutional investors operating at the Nairobi Stock Exchange. International Journal of Business and Emerging Markets, 1(1), 24-41.

\section{Funding}

Authors declare receiving no funding or financial support in carrying out the research.

Conflict of interest

Authors declare no conflict of interest in the research work. 